\title{
Simulation of Wheat Yield Using the RZWQM as Affected by Supplemental Irrigation in the North Western Coast of Egypt
}

\author{
A.N.El-Sadek and E.M.M. Salem \\ Plant Production Department, Ecology and Dry land \\ Agriculture Division, Desert Research Center, Cairo, Egypt.
}

\begin{abstract}
$\mathrm{I}_{\mathrm{N}}$ $\mathrm{N}$ ARID and semi-arid regions, the amount of rainfall and its distribution greatly affect the productivity of crops in these regions. Rainfall deficits during the critical growth stages can cause a sever crop yield losses. The study was carried out at the agricultural Experimental station, Sustainable Development Center of Matrouh Resources, Egypt, during 2014/2015 and 2015/2016 rainfall seasons to evaluate the effect of different supplemental irrigation treatments on wheat yield. The irrigation treatments included rainfall only (control), one irrigation of $50 \mathrm{~mm}$ at tillering or booting or grain filling, two irrigations of $100 \mathrm{~mm}$ at tillering and booting or tillering and grain filling or booting and grain filling, and three irrigations of $150 \mathrm{~mm}$ at the three stages of tillering, booting and grain filling. The obtained results showed that the application of supplemental irrigation of $150 \mathrm{~mm}$ at the three stages of tillering, booting and filling secured the highest significantly values of plant height $(61.47 \mathrm{~cm})$, spike length $(9.07 \mathrm{~cm})$ and number of grains/spike (46.67) in the first season only, 1000 grain weight (39.72 and $48.53 \mathrm{~g})$, biological yield (5.10 and $8.72 \mathrm{t} / \mathrm{ha})$, grain yield $(1.55$ and $3.40 \mathrm{t} / \mathrm{ha})$, straw yield (3.54 and $5.35 \mathrm{t} / \mathrm{ha})$ and WUE $\left(0.672\right.$ and $\left.1.08 \mathrm{~kg} / \mathrm{m}^{3}\right)$ in both seasons, respectively. Wheat yield in the second season under the different supplemental irrigation treatments was simulated using the Root Zone Water Quality Model. Results showed a very good agreement between simulated and observed yields with a NashSutcliff Efficiency (NSE) of 0.93 . It could be concluded that supplemental irrigation is highly important for achieving a good economic yield of wheat under the rainfed condition of Matrouh Governorate, moreover the RZWQM successfully simulated the wheat yield under water stress conditions.
\end{abstract}

Keywords: Supplemental irrigation, RZWQM, Rainfed wheat, Yield and its components, WUE.

Egypt is the world's largest wheat importer with 11 million tones for the 2015/2016 marketing year (FAO, 2016). Most of Egypt's agricultural lands is irrigated and is concentrated in the rural areas of the Nile Valley and Delta. The country is making significant efforts to close the trade gap by increasing the cultivated area of wheat. The rainfed area of the North Western Coastal Zone 
(NWCZ) from Alexandria to El-Salloum on the Libyan border, has promising opportunities for sustainable agriculture development. Rainfall over the area is characterized by low annual amount (130 - $150 \mathrm{~mm}$ on average), high spatial and temporal variability and unfavorable seasonal distribution for crop production.

Drought tolerant crops such as wheat, barley, fig, olive and small areas with faba bean and lentil are the predominant cultivated crops in the area. The low amount of rain during the winter wheat growing seasons only provides $30 \%$ of the crop water requirements, and almost $70 \%$ of irrigation water is required to maintain the potential yield of winter wheat (Ouda, 2016). Long dry spells usually occurs during the critical growth stages i.e., flowering and grain filling which severely affect the final yield (Oweis \& Hachum, 2006). The mean grain yield of wheat in this area ranges from 0.35 to $2 \mathrm{t} / \mathrm{ha}$ based on the rainfall amount and distribution, soil characteristics and used variety, which is a way far from the country average of $7.3 \mathrm{t} / \mathrm{ha}$. Using limited amount of water as a supplemental irrigation can improve both the crop productivity and increase the water use efficiency (Man et al., 2016), they found that the supplemental irrigation treatment of increasing the soil water content at depth of $40 \mathrm{~cm}$ to $65 \%$ of field capacity after jointing and $70 \%$ of field capacity after anthesis increased the grain yield and water use efficiency by above $40 \%$ and $15 \%$, respectively in both seasons.

Many researchers have reported that using different supplemental irrigation quantities at certain specific growth stages of wheat increased significantly grain yield (Ilbeyi et al., 2006; Benli et al., 2007; Xiao et al., 2007; Erekul et al., 2012 and Tadayon et al., 2012.). In Texas high plains, USA, Attia et al. (2016) showed that the triple irrigation with a total of $300 \mathrm{~mm}$ at jointing, booting and anthesis as well as douple irrigation of $220 \mathrm{~mm}$ ( $100 \mathrm{~mm}$ at jointing and $120 \mathrm{~mm}$ at anthesis) produced a similar yield to the full irrigation $(400 \mathrm{~mm})$. While the highest water use efficiency of $13 \mathrm{~kg} \mathrm{ha}^{-1} \mathrm{~mm}^{-1}$ was at the single irrigation of 140 $\mathrm{mm}$ at the grain filling stage. These results confirming that irrigation timing is critical in determining wheat production under water-limited conditions.

Crop simulation models are powerful tools to evaluate different agronomic management practices after careful calibration. RZWQM2 combined the root zone water quality model (RZWQM) (Ahuja, 2000) with the decision support system for agro technology transfer (DSSAT), (Hoogenboom et al., 2004) and it has been successfully used to simulate water availability, crop production and crop management practices. In a long term simulation, Qi et al. (2013) used the RZWQM2 to simulate the soil water and wheat yield under different management practices, i.e., tillage methods, planting dates and seeding rates. The model showed no impact of the tillage methods on the wheat yield and a reduction in the yield by delaying the planting date. Fang et al. (2010) evaluated various irrigation strategies in wheat-maize double cropping system in the North China plain using the RZWQM. Crop yield response to different irrigation scheduling was adequately simulated with a $\mathrm{r}^{2}$ of 0.90 and NMSE of 0.87 . Egypt. J. Agron . 38, No.2 (2016) 
Limited information is available in the simulation of wheat water use and yield under rainfed dry conditions.

Therefore the present investigation aimed to:1) Determine the response of wheat yield and its components and the water use efficiency to different timing and quantity of supplemental irrigation and 2) Evaluate RZWQM2 for its prediction of crop yield in response to different supplemental irrigation treatments under the NWCZ of Egypt.

\section{Experimental site \\ Materials and Methods}

Two field experiments were conducted during the growing seasons of 2014/2015 and 2015/2016 at the Agricultural Research Station, Sustainable Development Center of Matrouh Resources, Desert Research Center that is located in Matrouh Governorate, Egypt $\left(31.35^{\circ} \mathrm{N}, 27.18 \mathrm{E}\right)$ and is at $9 \mathrm{~m}$ in altitude .The region has a typical Mediterranean environment, rainfall was 81.60 $\mathrm{mm}$ in the first season and $239 \mathrm{~mm}$ in the second season. The soil is sandy clay loam, which is strongly calcareous $\left(17.5 \% \mathrm{CaCo}_{3}\right)$, with an $\mathrm{EC}$ of $0.223 \mathrm{dS} / \mathrm{m}$ and $\mathrm{pH}$ of 8.2.

\section{Treatments and experimental design}

Wheat cultivar Giza 168 was sown in 30 Nov., 2014 for the first season and in 17 Nov., 2015 for the second season. The cultivar was chosen based on its high productivity under the rainfed condition of the area, the seeding rate was $100 \mathrm{~kg} / \mathrm{ha}$. Plot size was $6 \mathrm{~m}^{2}(2 \times 3 \mathrm{~m})$ with row spacing of $25 \mathrm{~cm}$, there were 32 plots. A $57 \mathrm{~g} /$ plot of grains was sown by hand.

The experiment was laid out in a randomized complete block design (RCBD) in four replicates, each replicate had seven supplemental irrigation treatments plus the control. Supplemental irrigation treatments included; $\mathrm{T}_{0}$ is rainfed only as control ( without supplemental irrigation); $T_{1}$ is one irrigation $(50 \mathrm{~mm}$ ) at tillering, $T_{2}$ is one irrigation $(50 \mathrm{~mm})$ at booting, $T_{3}$ is one irrigation $(50 \mathrm{~mm})$ at filling, $\mathrm{T}_{4}$ is two irrigations $(100 \mathrm{~mm})$ at tillering and booting, $\mathrm{T}_{5}$ is two irrigations $(100 \mathrm{~mm})$ at tillering and filling, $\mathrm{T}_{6}$ is two irrigations $(100 \mathrm{~mm})$ at booting and filling and $T_{7}$ is three irrigations $(150 \mathrm{~mm})$ at the three stages of tillering, booting and filling. irrigations were applied through a drip irrigation system.

The plants were harvested from an area of $6 \mathrm{~m}^{2}$ (plot area). Grain, straw and biological yields/ha were based on the land area. No fertilizer applications were applied to the plants as is practiced by the local farmers in the region. The plants were harvested in 3/4/2015 for the first season and in 15/4/2016 for the second season.

\section{Sampling and measurements}

During the two growing seasons, ten guarded plants were chosen randomly from each plot to record the following criteria; plant height $(\mathrm{cm})$, spike length 
(cm), No. grains/spike, 1000-grain weight $(\mathrm{g})$. The plants from the entire plot were harvested to record grain yield $(\mathrm{kg} / \mathrm{ha})$, straw yield $(\mathrm{kg} / \mathrm{ha})$ and biological yield $(\mathrm{kg} / \mathrm{ha})$. The harvest index $(\%)$ and crop index $(\%)$ were calculated as the percentage ratio of grain yield to the biological yield and the straw yield, respectively. The water use efficiency (grain yield $\mathrm{kg} / \mathrm{m}^{3}$ of water) was calculated as the ratio of the unit area wheat yield to the sum of the total irrigation (rainfall + supplemental irrigation) during the growing season.

\section{Statistical analysis}

Analysis of variance (ANOVA) was performed to determine the significance of the main effects and their interaction. Least significance difference (LSD) tests were performed to determine the significant differences between individual means. All statistical analyses were performed using the Cropstat version 7.2 statistical software (CropStat, 2009).

\section{Root zone water quality model (RZWQM2)}

RZWQM2 is a one-dimensional model with emphasis on management effects on water quantity, water quality and crop production. It runs on a daily time step for crop growth, $\mathrm{N}$ balance and pesticide modules; a sub-hourly time step is used for soil water, soil heat transfer, and surface energy balance modules.

The model contains plant growth modules for 22 field crops from the DSSAT crop modules (Ma et al., 2011). RZWQM2 originally had a generic plant growth module that could be parameterized for any annual crop. It is currently parameterized mainly for maize, soybean and winter wheat. Minimum model inputs required are rainfall (amount and intensity), daily or hourly weather, site description, soil properties, initial soil water condition, crop information and management practices. A complete description of the model use, capabilities, calibration and validation are already described in details in (Ma et al., 2012a).

Soil water content is one of the most commonly measured data available in field research. The average water content at $33 \mathrm{kPa}\left(\theta_{1 / 3}\right)$ suction of 0.1647 and at $1500 \mathrm{kPa}\left(\theta_{15}\right)$ suction of 0.0741 were used to estimate Brooks-Corey parameters. The saturated soil hydraulic conductivity (Ksat) of $0.31 \mathrm{~cm} / \mathrm{h}$ was used. These values were collected from the literature of previous studies in the area, as these parameters have the most effect on soil water distribution. If measurements are not available, the model provides average values for these parameters based on soil texture as default values.

\section{Model evaluation}

To evaluate the model performance and compare the simulated versus the observed results, three statistical measurements were used: The coefficient of determination $\left(\mathrm{R}^{2}\right)$, Nash- Sutcliff efficiency (NSE) (Nash \& Sutcliffe, 1970), and the root mean square error (RMSE)-observation's standard deviation ratio (SR) collectively called RSR ( Eq. 1,2 and 3). 
The $\mathrm{R}^{2}$ describes the degree of collinearity between simulated and measured data and describes the proportion of the variance in measured data explained by the model. $\mathrm{R}^{2}$ ranges from 0 to 1 , with higher values indicating less error variance.

$\boldsymbol{R}^{2}=\frac{\left[\sum_{i=1}^{n}\left(\boldsymbol{O}_{i}-\overline{\boldsymbol{O}}\right)\left(\boldsymbol{P}_{i}-\overline{\boldsymbol{P}}\right)\right]^{2}}{\left[\sum_{i=1}^{n}\left(\boldsymbol{O}_{i}-\overline{\boldsymbol{O}}\right)^{2}\right]\left[\sum_{i=1}^{n}\left(\boldsymbol{P}_{i}-\overline{\boldsymbol{P}}\right)^{2}\right]}$

The NSE measures the predictive power of the model and how well the plot of observed versus simulated value fits the 1:1 line, it ranges between $-\infty$ and 1 , with $\mathrm{NSE}=1$ corresponds to a perfect match between predicted and observed data, whereas values $\leq 0$ indicate that the mean observed value is a better predictor than the simulated value (Moriasi, et al., 2007).

$N S E=\frac{\sum_{i=1}^{n}\left(\boldsymbol{O}_{i}-\overline{\boldsymbol{O}}\right)^{2}-\sum_{i=1}^{n}\left(\boldsymbol{P}_{i}-\boldsymbol{O}_{i}\right)^{2}}{\sum_{i=1}^{n}\left(\boldsymbol{O}_{i}-\overline{\boldsymbol{O}}\right)^{2}}$

The RSR is a commonly used error index; it is calculated as a ratio of the RMSE and standard deviation of the measured data. The RSR value varies from the optimal value of 0 , which indicates zero RMSE or residual variation and a perfect model simulation, to a large positive value, the lower the RSR, the better the model performance.

$\boldsymbol{R S R}=\frac{\boldsymbol{R M S E}}{\operatorname{STDEV_{obs}}}=\frac{\left\lfloor\sqrt{\sum_{i=1}^{n}\left(\boldsymbol{O}_{\bar{i}}-\boldsymbol{P}_{i}\right)^{2}}\right\rfloor}{\left[\sqrt{\sum_{i=1}^{n}\left(\boldsymbol{O}_{i}-\overline{\boldsymbol{O}}\right)^{2}}\right]}$

where, $\mathrm{P}_{\mathrm{i}}$ are the predicted values, $\mathrm{O}_{\mathrm{i}}$ are the observed values, $\mathrm{n}$ is the total number of observations, $\bar{O}$ is the mean of the observed data and $\bar{P}$ is the mean of the predicted data. STDEV ${ }_{\text {obs }}$ is the standard deviation of observed values.

\section{Results and Discussion}

Effect of supplemental irrigation treatments on wheat grain yield, its components, and water use efficiency

Results in Tables 1 and 2 show that all yield, its components, harvest index, crop index and water use efficiency (WUE) were significantly affected by supplemental irrigation treatments. Generally, plant height $(\mathrm{cm})$, number of grains/spike, 1000 grain weight $(\mathrm{g})$, biological, grain and straw yields (kg/ha) as well as WUE $\left(\mathrm{kg} / \mathrm{m}^{3}\right)$ were markedly improved with increasing the supplemental irrigation levels. So, $\mathrm{T}_{7}$ treatment (three supplemental irrigations by $150 \mathrm{~mm}$ at tillering, booting and filling stages) was the most efficient treatment in this connection being recorded the highest values of the above mentioned traits in the two seasons except, spike length $(\mathrm{cm})$ and number of grains/spike ( in the first 
season only). While, the highest values of spike length and number of grains/spike were obtained with $\mathrm{T}_{6}$ treatment (two supplemental irrigations by $100 \mathrm{~mm}$ at booting and filling stages) in the second season only. $\mathrm{T}_{0}$ treatment (without supplemental irrigation or rainfed only) was inferior treatment for all the aforementioned traits in the two seasons except, straw yield in the second season. However, $\mathrm{T}_{3}$ treatment ( one supplemental irrigation by $50 \mathrm{~mm}$ at filling stage) gave the lowest value for this trait in the first season only. These findings are in agreement with those of Erekul et al. (2012), Tadayon et al. (2012), Abbas et al. (2014), Attia et al. (2016) and Man et al. (2016).

The superiority of $T_{7}$ treatment (three supplemental irrigations by $150 \mathrm{~mm}$ at tillering, booting and filling stages) in biological, grain and straw yields and WUE may be resulted from the improvement in the yield components i.e., spike length, number of grains/spike and 1000 grain weight (Tables 1 and 2). Water plays many essential roles in plant growth i.e., helps to maintain the turgidity of cell walls necessary for cell enlargement and growth, acts as a solvent for nutrients to be absorbed by plant, is used for photosynthesis and end products are conveyed through water from cell to cell and organ to organ, so sufficient water increases dry matter, growth and the photosynthesis products accumulation in the sink (Salem et al., 2003). Also, Xue et al. (2003 and 2006) indicated that supplemental irrigation of winter wheat between the jointing and flowering stages significantly improved grain yield and WUE due to increased photosynthetic activity and remobilization of pre-anthesis carbon reserves.

TABLE 1. Effect of supplemental irrigation treatments on wheat grain yield, its components and water use efficiency (2014/2015 growing season).

\begin{tabular}{|c|c|c|c|c|c|c|c|c|c|c|}
\hline 苛 & 氖 & 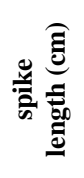 & 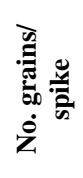 & 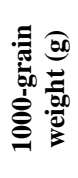 & 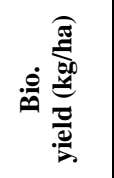 & 焉 & 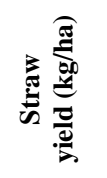 & E & च 8 & 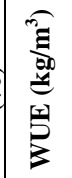 \\
\hline$T_{0}$ & 23.30 & 5.10 & 8.33 & 13.33 & 900.32 & 173.13 & 727.19 & 19.22 & 23.94 & 0.213 \\
\hline$T_{1}$ & 40.67 & 7.00 & 15.33 & 17.10 & 1853.71 & 435.16 & 1418.56 & 24.11 & 31.82 & 0.239 \\
\hline$T_{2}$ & 45.33 & 8.00 & 18.33 & 19.83 & 2517.35 & 540.89 & 1976.46 & 21.32 & 27.16 & 0.297 \\
\hline$T_{3}$ & 44.67 & 7.67 & 20.67 & 23.50 & 1257.85 & 586.55 & 671.31 & 46.60 & 87.41 & 0.445 \\
\hline$T_{4}$ & 48.67 & 5.43 & 25.00 & 23.13 & 2423.00 & 572.08 & 1850.92 & 23.60 & 30.90 & 0.434 \\
\hline$T_{5}$ & 45.67 & 8.67 & 24.00 & 18.40 & 2708.17 & 623.04 & 2085.13 & 22.99 & 29.88 & 0.473 \\
\hline$T_{6}$ & 48.20 & 6.90 & 31.00 & 27.77 & 3265.88 & 787.27 & 2478.61 & 24.13 & 31.82 & 0.445 \\
\hline$T_{7}$ & 61.47 & 9.07 & 46.67 & 39.72 & 5095.54 & 1552.66 & 3542.88 & 30.45 & 43.79 & 0.672 \\
\hline LSD & 5.82 & 1.05 & 5.10 & 5.87 & 1010.9 & 230.1 & 794.64 & 3.07 & 6.05 & 0.127 \\
\hline
\end{tabular}

Whereas: $T_{0}$ is rainfed only, $T_{1}$ is one irrigation $50 \mathrm{~mm}$ at tillering, $\mathrm{T}_{2}$ is one irrigation $50 \mathrm{~mm}$ at booting, $T_{3}$ is one irrigation $50 \mathrm{~mm}$ at filling, $\mathrm{T}_{4}$ is two irrigations $(100 \mathrm{~mm})$ at tillering and booting, $\mathrm{T}_{5}$ is two irrigations $(100 \mathrm{~mm})$ at tillering and filling, $\mathrm{T}_{6}$ is two irrigations $(100 \mathrm{~mm})$ at booting and filling and $\mathrm{T}_{7}$ is three irrigations $(150 \mathrm{~mm})$ at the three stages of tillering, booting and filling, HI is harvest index, CI is crop index, WUE is water use efficiency, LSD is least significant differences.

Egypt. J. Agron. 38, No.2 (2016) 
TABLE 2. Effect of supplemental irrigation treatments on wheat grain yield, its components and water use efficiency (2015/2016 growing season).

\begin{tabular}{|c|c|c|c|c|c|c|c|c|c|c|}
\hline 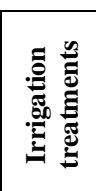 & 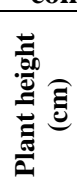 & 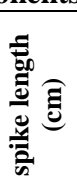 & 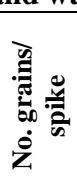 & 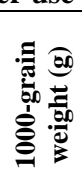 & 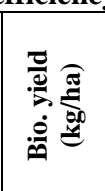 & 胥 & 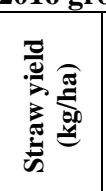 & 国 & 已 & 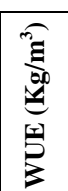 \\
\hline$T_{0}$ & 43.25 & 5.50 & 21.75 & 26.50 & 1637.7 & 379.25 & 1258.43 & 23.27 & 30.50 & 0.233 \\
\hline$T_{1}$ & 56.50 & 7.25 & 26.00 & 30.40 & 4101.17 & 981.58 & 3119.58 & 23.91 & 31.57 & 0.373 \\
\hline$T_{2}$ & 58.00 & 9.00 & 34.00 & 32.13 & 4411.21 & 1354.61 & 3056.60 & 30.86 & 44.73 & 0.636 \\
\hline$T_{3}$ & 57.25 & 7.75 & 43.00 & 32.48 & 4742.02 & 1733.18 & 3008.90 & 36.51 & 57.63 & 0.814 \\
\hline$T_{4}$ & 59.00 & 8.50 & 47.75 & 33.47 & 5574.62 & 1976.70 & 3597.93 & 35.49 & 55.23 & 0.928 \\
\hline$T_{5}$ & 60.50 & 7.75 & 46.25 & 37.16 & 5837.17 & 2378.94 & 3458.23 & 40.77 & 68.84 & 0.905 \\
\hline$T_{6}$ & 50.00 & 9.50 & 56.50 & 41.50 & 5525.84 & 2599.45 & 2925.59 & 47.13 & 90.15 & 0.988 \\
\hline$T_{7}$ & 72.00 & 7.75 & 56.25 & 48.53 & 8715.21 & 3400.54 & 5350.67 & 38.65 & 63.55 & 1.08 \\
\hline LSD & 4.88 & 1.17 & 4.42 & 4.31 & 516.41 & 383.15 & 357.26 & 4.60 & 12.54 & 0.134 \\
\hline
\end{tabular}

Whereas; $\mathrm{T}_{0}$ is rainfed only, $\mathrm{T}_{1}$ is one irrigation $50 \mathrm{~mm}$ at tillering, $\mathrm{T}_{2}$ is one irrigation $50 \mathrm{~mm}$ a booting, $T_{3}$ is one irrigation $50 \mathrm{~mm}$ at filling, $\mathrm{T}_{4}$ is two irrigations $(100 \mathrm{~mm})$ at tillering and booting, $\mathrm{T}_{5}$ is two irrigations $(100 \mathrm{~mm})$ at tillering and filling, $\mathrm{T}_{6}$ is two irrigations $(100 \mathrm{~mm})$ at booting and filling and $\mathrm{T}_{7}$ is three irrigations $(150 \mathrm{~mm})$ at the three stages of tillering, booting and filling, $\mathrm{HI}$ is harvest index, $\mathrm{CI}$ is crop index, WUE is water use efficiency, LSD is least significant differences.

In the dry season (2014/2015) one irrigated treatment of $50 \mathrm{~mm}$ at tillering or booting or grain filling, increased the grain yield by $151 \%, 212 \%$ and $239 \%$ and the water use efficiency by $12.2 \%, 39.4 \%$ and $108.9 \%$ over the rainfed only treatment, respectively. Attia et al. (2016) found that one irrigation treatments of $100 \mathrm{~mm}$ at jointing or booting or $140 \mathrm{~mm}$ at anthesis or grain filling produced a better grain yield as compared to no supplemental irrigation. They also highlighted the importance of deficit irrigation treatment in decreasing the yield fluctuations in dry areas, and that it increased the WUE when it was applied at the grain filling stage as compared to its application at jointing or booting. Man et al. (2016) concluded that suitable irrigation at jointing and anthesis increases root weight density, root triphenyl tetrazolium chloride reduction activity, and root antioxidant enzyme activity at the later stages of grain filling.

It is evident from Tables 1 and 2 that the highest values of harvest and crop index (\%) exceeding the other treatments were obtained by $\mathrm{T}_{3}$ treatment (a one supplemental irrigation by $50 \mathrm{~mm}$ at filling stage) in the first season and $\mathrm{T}_{6}$ treatment (two supplemental irrigations by $100 \mathrm{~mm}$ at booting and filling stages) in the second season. While, the lowest values of the abovementioned traits were obtained by $\mathrm{T}_{0}$ treatment (without supplemental irrigation) in the two seasons. These results are supported by findings of Zhang et al. (2008) and Attia et al. (2016). 
Comparing the treatments of two supplemental irrigations by $100 \mathrm{~mm}$ on wheat yields, its components and WUE, our results reported that the $\mathrm{T}_{6}$ treatment (two supplemental irrigations by $100 \mathrm{~mm}$ at booting and filling stages) secured the highest values of the abovementioned traits except, WUE (in the second season only) as compared with $\mathrm{T}_{5}$ (two supplemental irrigations by $100 \mathrm{~mm}$ at tillering and filling stages) and $\mathrm{T}_{4}$ (two supplemental irrigations by $100 \mathrm{~mm}$ at tillering and booting stages) treatments in both seasons as shown in Tables 1 and 2. These results are in similar trend with those of Zhang et al. (2008) and Attia et al. (2016).

\section{RZWQM2 model evaluation to simulate wheat yield}

The model was first calibrated manually to one irrigation treatment, i.e., $\mathrm{T} 7$ then was validated for the other irrigation treatments, for these purposes we used a complete datasets related to the soil hydraulic characteristics and physical properties. Therefore the model evaluation procedures and results of this study are valid.

Data in Table 3 and Fig. 1 show the simulated and measured grain yield, biological yield and harvest index. Results show that the model tends to under predicted the grain yield and biological yields under all the irrigation treatments except for the rainfed and adding one irrigation at tillering and at filling for the grain yield, however it was at two irrigation treatments at tillering and filling $\left(\mathrm{T}_{5}\right)$ and at booting and filling $\left(\mathrm{T}_{6}\right)$ for the biological yield. The best match between measured and simulated values was at the treatment of a one supplemental irrigation at booting for both the grain and biological yields.

Goodness of fit measures, i.e., $\mathrm{R}^{2}$ and NSE revealed that there was a good match between simulated and measured yields with $\mathrm{R}^{2}$ value of 0.98 and NSE value of 0.93 for the grain yield. However, in the case of biological yield these values were 0.923 and 0.882 for the $\mathrm{R}^{2}$ and NSE values, respectively. The modeled poorly estimated the harvest index with a low $\mathrm{R}^{2}$ value of 0.342 and a negative NSE value of -0.535 which means the using of the observed average is a better predictor than using the model for this parameter.

The measured and simulated biological and crop yields responded similarly to the different irrigation treatments. Moreover, the RZWQM2 adequately simulated crop yield and biological yield in response to various supplemental irrigation practices, this is clear from the data presented in Table 3 that the highest grain yield and total biomass were recorded when the crop received three irrigation treatments, Many studies addressed the successful use of the RZWQM in simulating the crop growth under water stress conditions and irrigation scheduling (Ma et al., 2003, 2012b and Fang et al., 2010, 2014).

Egypt. J. Agron . 38, No.2 (2016) 
TABLE 3. Comparison between observed grain yield, biological yield and harvest index and the simulated values by the RZWQM2 in the second growing season (2015/2016).

\begin{tabular}{|c|c|c|c|c|c|c|}
\hline Treatment & $\begin{array}{l}S_{\text {yield }} \\
\text { t ha }^{-1}\end{array}$ & $\begin{array}{c}M_{\text {yield }} \\
\mathrm{t} \mathrm{ha}^{-1}\end{array}$ & $\begin{array}{c}S \\
\text { T.biomass } \\
\text { t ha }^{-1}\end{array}$ & $\begin{array}{c}M \\
\text { T.biomass }^{-1} \\
\text { t ha }^{-1}\end{array}$ & $S_{\mathrm{HI}}(\%)$ & $M_{\mathrm{HI}}(\%)$ \\
\hline $\mathrm{T}_{0}$ & 0.47 & 0.38 & 1.26 & 1.64 & 0.37 & 0.23 \\
\hline $\mathrm{T}_{1}$ & 1.14 & 0.98 & 2.8 & 4.1 & 0.41 & 0.24 \\
\hline $\mathrm{T}_{2}$ & 1.34 & 1.35 & 3.95 & 4.41 & 0.34 & 0.31 \\
\hline $\mathrm{T}_{3}$ & 1.81 & 1.73 & 4.68 & 4.74 & 0.39 & 0.36 \\
\hline $\mathrm{T}_{4}$ & 1.82 & 1.98 & 5.37 & 5.57 & 0.34 & 0.35 \\
\hline $\mathrm{T}_{5}$ & 2.21 & 2.38 & 6.36 & 5.84 & 0.35 & 0.41 \\
\hline $\mathrm{T}_{6}$ & 2.22 & 2.6 & 6.45 & 5.53 & 0.34 & 0.47 \\
\hline $\mathrm{T}_{7}$ & 2.97 & 3.4 & 8.49 & 8.72 & 0.35 & 0.38 \\
\hline$* \mathrm{R}^{2}$ & \multicolumn{2}{|c|}{0.98} & \multicolumn{2}{|c|}{0.923} & \multicolumn{2}{|c|}{0.342} \\
\hline NSE & \multicolumn{2}{|c|}{0.93} & \multicolumn{2}{|c|}{0.882} & \multicolumn{2}{|c|}{-0.535} \\
\hline RSR & \multicolumn{2}{|c|}{0.24} & \multicolumn{2}{|c|}{0.32} & \multicolumn{2}{|c|}{1.16} \\
\hline
\end{tabular}

$S_{\text {yield }}$ is the simulated yield; $M_{\text {yield }}$ is the measured yield; $S_{\text {T.biomass }}$ is the simulated total biomass; $M$ T.biomass is the measured biomass, $\mathrm{HI}$ is harvest index; $\mathrm{T}_{0}$ is rainfed only, $\mathrm{T}_{1}$ is one irrigation $50 \mathrm{~mm}$ at tillering, $T_{2}$ is one irrigation $50 \mathrm{~mm}$ at booting, $T_{3}$ is one irrigation $50 \mathrm{~mm}$ at filling, $T_{4}$ is two irrigations $(100 \mathrm{~mm})$ at tillering and booting, $\mathrm{T}_{5}$ is two irrigations $(100 \mathrm{~mm})$ at tillering and filling, $T_{6}$ is two irrigations $(100 \mathrm{~mm})$ at booting and filling and $T_{7}$ is three irrigations $(150 \mathrm{~mm})$ at the three stages of tillering, booting and filling, .* $\mathrm{R}^{2}$ is the coefficient of determination, NSE: Nash- Sutcliff Efficiency, RSR: the Root Mean Square Error (RMSE)-observation's standard deviation ratio (SR).
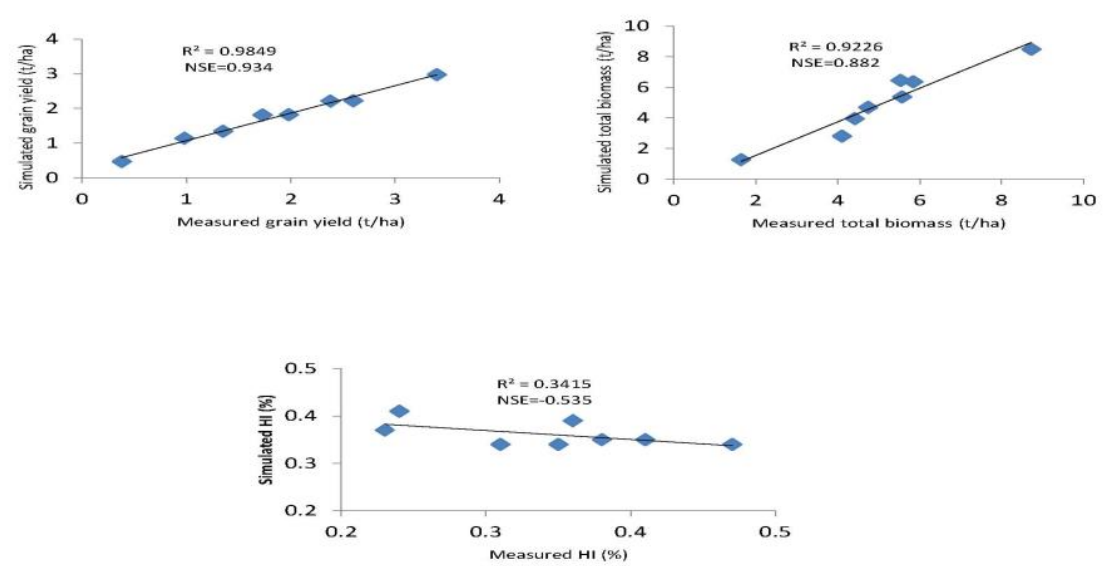

Fig. 1. Measured versus simulated grain yield (t/ha), total biomass (t/ha) and harvest index (\%) and the associated values of $\mathbf{R}^{2}$ and NSE.

Egypt. J. Agron . 38, No. 2 (2016) 
Testing the RZWQM2 for the different irrigation treatments for the second season demonstrated the importance of good and comprehensive data sets for model validation. The results of evaluating the RZWQM for water stress show that the model can be calibrated well for a given irrigation treatment (e.g. $T_{7}$ irrigation treatment). But the prediction capability of the model for other treatment varies. The model well simulated the response of the crop yield to the irrigation treatments i.e., increasing the number of supplemental irrigation treatments increased the grain and biological yields. This is very important for using the model to simulate the crop growth and yield under water stress and rainfed conditions.

Additional field experiments are necessary to study the effect of soil moisture conditions at planting and weather variability on winter wheat growth and yield in the arid areas of NWCZ of Egypt.

Supplemental irrigation is an effective agricultural practice to mitigated the adverse impact of dry spell during the critical growth periods. However, the amount of the added water is insufficient to produce the crop potential yield, so it is important to maximize the utilization of low rainfall in the NWCZ region by implementing different soil and water conservation practices. one of these practices include the water harvesting technology, i.e., the furrow ridge water harvesting system (FRWHS) which proved to increase the crop productivity in the area (El-Sadek \& Salem, 2015). Xiao et al. (2007) showed that using the supplemental irrigation of $40 \mathrm{~mm}$ and $59 \mathrm{~mm}$ during the entire growth period combined with the FRWHS can reach 2000 and $2250 \mathrm{~kg} \mathrm{ha}^{-1}$,respectively in the semi-arid areas of China.

\section{Conclusion}

In view of the abovementioned results, worthily clear that under the dry conditions of the North Western Coast zone of Egypt where the agriculture system mainly dependent on rainfall only, it is a dire need to supplemental irrigation to enhance the productivity of wheat grain yield under this conditions.

In the case limited of irrigation water quantities, a one supplemental irrigation by $50 \mathrm{~mm}$ at filling stage is the economic treatment to improve the wheat grain yield and WUE. On the other side, in the case abundant of irrigation water quantities, two supplemental irrigations by $100 \mathrm{~mm}$ at booting and filling stages is the potent practice to enhance the productivity of wheat grain yield and WUE. While, using three supplemental irrigations by $150 \mathrm{~mm}$ at tillering, booting and filling stages is the best cardinal method in order to attain the highest productivity of wheat grain yield and WUE. 
RZWQM adequately simulated crop yield, total biomass and in some cases harvest index in response to the supplemental irrigation. The high correlation between simulated and measured crop yield $\left(\mathrm{R}^{2}=0.985\right.$ and NSE $\left.=0.934\right)$ and between simulated and measured aboveground biomass $\left(\mathrm{R}^{2}=0.923\right.$ and NSE $=$ 0.882 ) showed that the model correctly simulated crop responses to irrigation scheduling at various growth stages.

\section{References}

Abbas, S. H., Bhatt, A. A., Asif, M., Islam, Z., Sohail, M., Din, R. U., Qamar, M., Ali, M., Majeed, A. and Munir, M. (2014) Effect of supplemental irrigation on wheat water productivity under rainfed ecology of Pothohar, Pakistan. Innovare J. Agric. Sci. 3 (1), 10-13.

Ahuja, L. R., Rojas, K. W., Hanson, J. D., Shaffer, M. J. and Ma, L. ( 2000) "Root Zone Water Quality Model: Modeling Management Effects on Water Quality and Crop Production”. Water Resour. Publ., Highlands Ranch, CO.

Attia, A., Rajan, N., Xue, Q., Nair, S., Ibrahim, A. and Hays, D. (2016) Application of DSSAT-CERES-Wheat model to simulate winter wheat response to irrigation management in the Texas High Plains. Agric. Water Manage. 165, 50-60.

Benli, B., Pala, M., Stockle, C. and Oweis, T. (2007) Assessment of winter wheat production under early sowing with supplemental irrigation in a cold highland environment using CropSyst simulation model. Agric. Water Manage. 93, 45-53.

CropStat 7.2 for Windows Tutorial Manual (2009) Crop Research Informatics Laboratory. International Rice Research Institute. pp, 379.

El-Sadek, A. and Salem, E. (2015) Impact of ridge-furrow water harvesting system on faba bean (Vicia faba L.) production under rainfed conditions in Matrouh, Egypt. Ann. Agric. Sci. 60(1), 61-66

Erekul, O., Gotz, K. P. and Gurbuz, T. (2012) Effect of supplemental irrigation on yield and bread-making quality of wheat (Triticum aestivum L.) varieties under the Mediterranean climatical conditions. Turk. J. Field Crops,17(1),78-86.

Fang, Q., Ma, L., Yu, Q., Ahuja, L. R. , Malone, R. W. and Hoogenboom, G. (2010) Irrigation strategies to improve the water use efficiency of wheatmaize double cropping systems in North China Plain. Agric. Water Manage. 97, 1165-1174.

Fang, Q. X., Ma, L., Nielsen, D. C., Tout, T. J. and Ahuja, L. R. (2014) Quantifying corn yield and water use efficiency under growth stage-based deficit irrigation conditions. Adv. Agric. Syst. Mod. 5,1-24.

FAO Report (2016) Online available at http://www.fao.org/giews/ countrybrief/ country. jsp? code $=$ EGY. 
Hoogenboom, G., Jones, J. W., Wilkens, P. W., Porter, C. H., Batchelor, W. D., Hunt, L. A.,Boote, K. J., Singh, U., Uryasev, O., Bowen, W. T., Gijsman, A. J., du Toit, A., White,J. W. and Tsuji, G.Y. (2004) Decision Support System for Agrotechnology Transfer. Version 4.0. University of Hawaii, Honolulu, HI (CDROM).

Ilbeyi, A., Ustun, H., Oweis, T., Pala, M. and Benli, B. (2006) Wheat water productivity and yield in a cool highland environment: Effect of early sowing with supplemental irrigation. Agric. Water Manage. 82, 399-410.

Ma, L., Nielsen, D. C., Ahujaa, L. R., Malone, R. W. Saseendran, S. A., Rojas, K.W., Hanson, J. D. and Benjamin, J. G. (2003) Evaluation of RZWQM under varying irrigation levels in Eastern Colorado. Trans. ASABE. 46, 39-49.

Ma, L., Ahuja, L. R., Saseendran, S. A., Malone, R. W., Green, T. R., Nolan, B. T., Bartling, P. N. S., Flerchinger, G. N., Boote, K. J. and Hoogenboom, G. (2011) A protocol for parameterization and calibration of RZWQM2 in field research. In: "Methods of Introducing System Models into Agricultural Research".

Ma, L., Ahuja, L. R., Nolan, B. T., Malone, R. W., Trout, T. J. and Qi, Z. (2012a) Root zone water quality model (RZWQM2): model use, calibration and validation. Trans. ASABE. 55(4), 1425-1446.

Ma, L., Trout, T.J., Ahuja L. R., Bausch, W. C., Saseendran, S. A., Malone, R. W. and Nielsen, D. C. (2012b) Calibrating RZWQM2 model for maize responses to deficit irrigation. Agric. Water Manage. 103, 140- 149.

Man, J., Shi, Y., Yu, Z. and Zhang, Y.( 2016) Root growth, soil water variation, and grain yield response of winter wheat to supplemental irrigation. Plant Prod. Sci. 19 (2), 193-205.

Moriasi, D. N., Arnold, J. G., Van Liew, M. W., Bingner, R. L., Harmel, R. D. and Veith, T.L. (2007) Model evaluation guidelines for systematic quantification of accuracy in watershed simulations. Trans. ASABE. 50 (3), 885-900.

Nash, J. E. and Sutcliffe, J. V.( 1970) River flow forecasting through conceptual models. Part 1: discussion of principles. J. Hydrol. 10, 282-290.

Ouda, S. (2016) "Major Crops and Water Scarcity in Egypt, Irrigation Water Management under Changing Climate". Springer Briefs in Water Science and Technology,126 pp.

Oweis, T. and Hachum, A. (2006) Water harvesting and supplemental irrigation for improved water productivity of dry farming systems in West Asia and North Africa. Agric. Water Manage. 80, 57-73.

Salem, E. M., Ashoub, M. A., Salem, M. O. and Hamed, M. F. (2003) Response of wheat to supplemental irrigation and fertilizer under North Western Coast of Egypt. Zagazig J. Agric. Res. 30 (4), 1343-1363. 
Tadayon, M. R., Ebrahimi, R. and Tadayyon, A. (2012) Increased water productivity of wheat under supplemental irrigation and nitrogen application in a semi-arid region. J. Agr. Sci. Tech. 14, 995-1003.

Xiao, G. Zhang, Q., Xiong, Y., Lin, M. and Wang, J. (2007) Integrating rainwater harvesting with supplemental irrigation into rain-fed spring wheat farming. Soil Till. Res. 93, 429-437.

Xue, Q., Zhu, Z., Musick, J. T., Stewart, B. A., and Dusek, D. A. (2003) Root growth and water uptake in winter wheat under deficit irrigation. Plant and Soil, 257, 151161.

Xue, Q., Zhu, Z., Musick, J. T., Stewart, B. A. and Dusek, A. D. (2006) Physiological mechanisms contributing to the increased water-use efficiency in winter wheat under deficit irrigation. J. Plant Phys. 163, 154-164.

Zhang, X., Chen, S., Sun, H., Pei, D. and Wang, Y. (2008) Dry matter, harvest index, grain yield and water use efficiency as affected by water supply in winter wheat. Irrig. Sci. 27, 1-10.

Qi, Z., Bartling, P. N. S., Jabro, J. D., Lenssen, A. W., Iversen, W. M., Ahuja, L. R., Ma, L., Allen, B. L. and Robert, E. G. (2013) Simulating dryland water availability and spring wheat production in the Northern Great Plains. Agron. J., 105 (1), 37-50.

(Received 25/7/2016; accepted 4/ 9/2016)

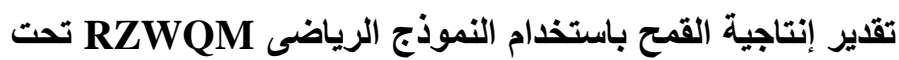
تأثير الرى التكميلى بالساحل الشمالى الغربحى لمصر

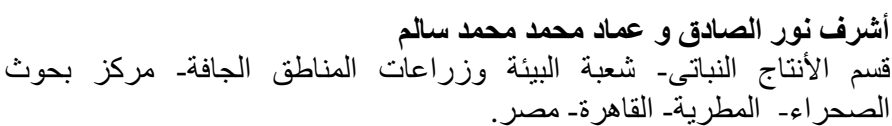

تؤثر كميات مياه الأمطار وتوزيعها بشكل كبير على إنتاجية المحاصيل بالمناطق

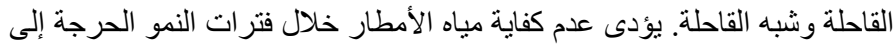

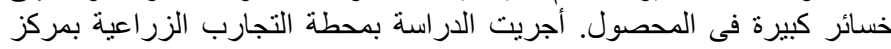

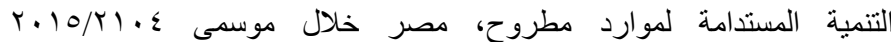

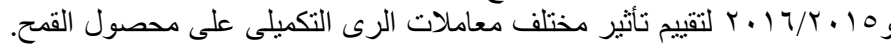

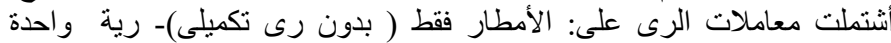

Egypt. J. Agron. 38, No. 2 (2016) 
بمقدار •0 مم (طور التفريع القاعدى، طور ما قبل طرد السنابل، طور إمتلاء

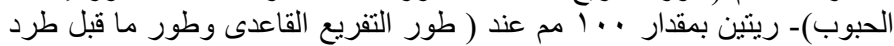

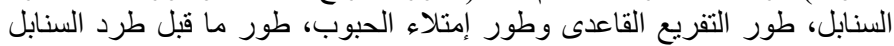

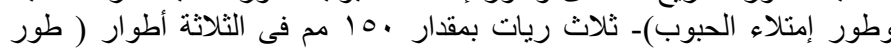

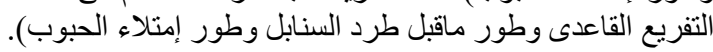

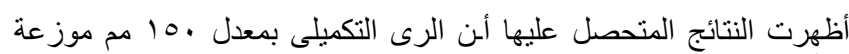

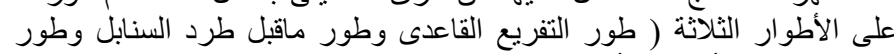

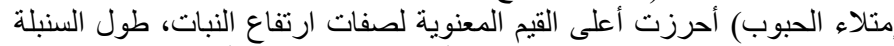

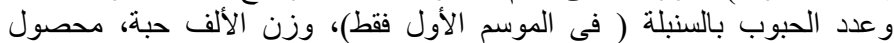
الحبوب والمصصول البيولوجى و ومحصول القش وكفاءة إستخدام الماء فى كلا لالا

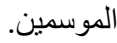

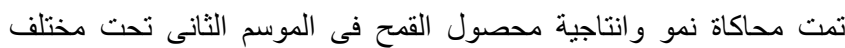

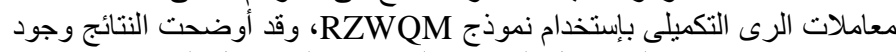

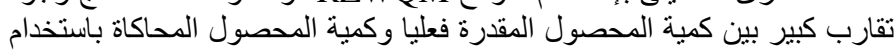
النموذج وكانت قيمة مقياس NSE هو كو بو , .

يمكن استتناج أن الرى التكميلى هام للغاية لتحقيق محصول أقتصادى جيد من

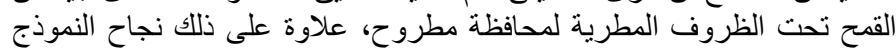
RZWQM بالساحل الثمالى الغربى لمصر. 